Article

\title{
Service and Pro-Existence in the Thought of the Romanian Theologian Dumitru Staniloae: A Path for the Orthodox Church Facing the Challenges of Globalization
}

\author{
Ionut Untea \\ School of Humanities, Department of Philosophy and Science, Wenke Building A, Jiulonghu Campus, \\ Southeast University, Nanjing 211189, China; untea_ionut@126.com or 108109055@seu.edu.cn \\ Academic Editor: John A. Jillions \\ Received: 3 April 2017; Accepted: 9 May 2017; Published: 16 May 2017
}

\begin{abstract}
Pro-existence" is a concept developed by 20th century western Christian theologians to describe the service of the Church facing contemporary challenges. The leading Romanian theologian Dumitru Staniloae (1903-1993) took this further by expressing his Orthodox understanding of the relationship between service and pro-existence. The article explores Staniloae's call for Orthodox Christians to serve not only people from other denominations, but those from other religions, as well as atheists. He depicted human pro-existence as an "existential impetus" towards serving the one in need, an impetus that the Orthodox Church should more visibly exercise. In a gentle, non-critical approach, Staniloae argues that the Orthodox Churches concentrated on liturgical service to God, while leaving service to people underdeveloped. The path ahead for the Orthodox Church will be the development of a harmonious multi-level understanding of pro-existence to hear and respond, as a "Serving" Church, to the needs of any human being.
\end{abstract}

Keywords: pro-existence; co-existence; Christian service; Orthodox Church; Christology; ecclesiology

\section{Introduction}

The term "pro-existence" appeared in various theological sources at the beginning of the second half of the twentieth century. In the late twentieth century, the term was already being used in Catholic and Protestant Christologies and Ecclesiologies. The Romanian theologian Dumitru Staniloae took the term from the Christian Peace Conference, founded in 1958, and in 1963 he dedicated an article to the relationship between service and pro-existence; an article which is practically unknown in international scholarship. Dumitru Staniloae's development of the relationship between service and pro-existence in the life of the Church shares many of the insights proposed by western Christian theologians, to which Staniloae adds a number of genuine views, which can be considered the fruit of his Orthodox understanding of the Church's mission to put into practice the relationship between service and pro-existence. Nonetheless, Staniloae's aim is not so much to enter into a debate with western theologians as to reinvigorate the Orthodox Church's understanding and practice of the pro-existential "impetus" of human nature into concrete acts of service between the members of a local Church and between local Churches themselves. In the first section of the article, I propose a brief analysis of the Catholic and Protestant understandings of service and pro-existence in the thought of a number of renowned theologians such as Dietrich Bonhoeffer, Josef Hromádka, Elisabeth Adler, Jon Sobrino, Aidan Nichols, Michel Deneken, Edward Schillebeeckx, François Xavier Durrwell, Walter Kasper, Heinz Schürmann, and Walter Klaiber, while in the second section, I will emphasize first the Romanian theologian's specific Orthodox contribution, and subsequently show the implications of Staniloae's ideas for the reception of a renewed sense of service within the Orthodox Church. 


\section{Two Approaches in Catholic and Protestant Theologies of Service and Pro-Existence in the Twentieth-Century and Beyond}

Early twentieth-century developments of the pro-existential aspect of the Church can be traced back to the Reformed theologian Karl Barth's Christology and especially to the Christological developments of his student, Dietrich Bonhoeffer, a theologian engaged in the ecumenical dialogue who was also a vocal preacher against the Nazi persecution of Jews and a concentration camp victim (Deneken 1988, pp. 286-87). In his letters from captivity (1943-1945), Bonhoeffer writes about the life of the Church (by which he understands the concrete manifestation of the Church's mission regarding the concrete needs of each parish, preaching, and the life of a Christian in a "religionless world"), and the necessity to take Christ as a model in "turbulent times" as the only hope for remembering "what it is that makes life really worth while "by virtue of Christ's example" as one whose only concern is for others" (Bonhoeffer 1959, pp. 123, 179, 184). This perspective of Jesus "being for" each individual has mainly generated two approaches in twentieth-century western theological thinking.

\subsection{The First Approach: Experiencing Pro-Existence as a Christian Immersed in Concrete Socio-Political Problems}

Without downgrading the theological implications of the attitude of "being for", and actually using theological arguments as a point of departure, the first approach consisted in emphasizing the essential vocation of each Christian to follow Christ's example in serving their neighbor, identifying the "neighbor" beyond confessional and religious boundaries. As in Bonhoeffer's case, this approach emerged more in contexts where political settings or social and economic infrastructures would be unfavorable for members of Christian Churches. The Christian Peace Conference founded in 1958 in Prague by the Czech Protestant theologian Josef Hromádka used the term pro-existence in its gatherings dedicated to promoting peace among countries of the Eastern bloc and in the world at large (Staniloae 1963, p. 1019). Hromádka's hopes, sometimes judged as naive by western interlocutors, were that the Soviet system would rather change over time, renouncing its oppressive character and making way for eastern European Christian heritage into the social application of Marxism (Bock 1992, p. 82). In a similar fashion, in the late 1950s and early 1960s, Christians of the German Democratic Republic (GDR) were using the term pro-existence to promote reciprocal relations of tolerance and mutual aid between Marxists and Christians, as part of their effort to show Marxist fellow citizens that Christians should not be viewed as enemies. In the preface of an 1964 English-language translation of several sermons of anonymous pastors of the GDR, Elisabeth Adler aims to counter two preconceived western attitudes towards Christians in Eastern Europe: the first, that they were "heroes of the faith", since they had chosen to be witnesses of faith and even martyrs in the social and political contexts prevailing under atheistic regimes; the second, that they were "traitors to the faith", having chosen certain degrees of compromise with those regimes. Neither of the two, Adler contends, can fully account for the realities encountered by Christians in such contexts in everyday life (Adler 1964, p. 7). That is why the term pro-existence was meant to invite a reconsideration of the relationships with the neighbor. She quotes a 1959 report of Protestant Student Congregations in the GDR that aimed at going "beyond the controversial thesis of co-existence to a practical 'pro-existence" and adds: "The word 'pro-existence' does of course run the risk of being little more than an attractive slogan. But it does seem to sum up in some measure what for Christians in the DDR [GDR] is the order of the day. [...] We have learnt that in our country there is no case to be made out for Christians simply going into hibernation, or just trying to save the Church alive during a period of atheistic attacks. [...] We have learnt, too, that we have no business breaking off relations with Communists and fellow-travelers, or with anxious and even apathetic souls outside the Church; instead, it is our business to create such relationships. [...] So it is not the Church we try to preserve now, but the Gospel. Preserving the Gospel means living the Gospel, and living the Gospel means pro-existence-being there for the world, just as Christ was there for the world" (Adler 1964, p. 13). 
As Elisabeth Adler has put it, the pro-existential vocation does not inspect the religious, intellectual, or social profile of the person in need, whether this person is an atheist, a non-Christian believer, or simply a fellow-traveler, but calls every Christian to service simply by virtue of the neighbors' sharing of human nature, since Christ came for all humankind. Viewing the atheists and non-Christians as fellow travelers in this world, side by side with Christians, would at the same time promote more peaceful relations between members and non-members of the Church and would encourage every Christian to live a more concrete life in the Gospel.

This focus on the specific need rather than on the specific profile of the neighbor and the image of a pro-existent Christ as a model for the Christian engaged in dealing with specific circumstances of life, be it political, economic, or religious, also attracted the theoretical attention of Jon Sobrino, a Catholic theologian known for his contributions to liberation theology. Sobrino understands that Jesus has come for all human beings, including the "oppressors" (Sobrino [1987] 2004, p. 34). Echoing the term "preferential option for the poor" established in Catholic theology by the Latin American Episcopal Council (CELAM) (Allen 2007), Sobrino's Christology sees Christ's person as transmitting to the world an example of "partisan pro-existence", by which he understands Christ's "existence in favor of certain other", the poor: "Stated systematically, Jesus's pro-existence consists, in a first moment, in a proclamation and toil calculated to further the passage of the poor from infra-existence to the existence of daughters and sons of God." (Sobrino [1987] 2004, p. 34). Given the official endorsement of the phrase "preferential option for the poor" by Pope John Paul II, by Cardinal Joseph Ratzinger, and by Pope Francis (Allen 2007; Gibson 2015), Sobrino's version of Jesus's "partisanship" of the poor shows how concrete social needs, in this case those of the Church in Latin America, can generate theological renewal in the Church.

Later developments of the term pro-existence as part of an approach dedicated to the concrete circumstances of life can also be identified in the ecclesiology of the Catholic theologian Aidan Nichols, in his reflection on the Anglican theologian John Milbank, founder of the Radical Orthodoxy movement, which attracted theologians from different confessions and aimed at a deeper engagement of the Church within the social and political sphere. Nichols believes that Millbank's ecclesiological attitude is to radically assert a pro-existence of the Church in the sense of Richard Hooker's respublica Christiana, which would confound Church and civil society in an indistinguishable mass, marginalizing the "story of grace and sin" in which not everything can be solved by the application of charity: "The Church 'pro-exists' for all humanity; but in the meanwhile, before her mission is divinely completed, she must 'co-exist' with other aggregates of the human members of the creation" (Nichols [2014] 1992, pp. 331-32). Nichols thus emphasizes the key issues of the second approach regarding the term pro-existence: a search not only for the cultivation of respectful and fraternal relations towards the neighbor, but also for the manifestation of the living body of Christ as a means of nourishment of Christians from the reality of Christ's presence, which would give them the capacity to recognize organizations that do not perceive, or are themselves the product of, the manifestation of sin in the world. With such "aggregates" (organizations, governments) being incompatible with the Church's mission, the Church should simply learn how to coexist.

If in the first approach, there is a tendency towards radical affirmation of Christ's life as a gift "for" every human being, sometimes giving the impression of a relativization of the distinction inside-outside Church, the second approach depicts pro-existence as a vocation inside the Church, cultivated and nourished by the Church's sacramental life. With minor variations, Catholic, as well as Protestant theologians producing views that can be integrated into a second approach see pro-existence in a close relationship with diakonia, a call to service emanating from the centrality of the Eucharistic sacrament of the Church. 
2.2. The Second Approach: Christian Service and Pro-Existence Immersed in the Institutional and Sacramental Life of the Church

The Catholic theologian Michel Deneken identifies in the theology of Edward Schillebeeckx, one of the most active theologians during the Second Vatican Council, an intimate relationship between Christ's ministry, the Christian vocation towards service to the neighbor, and the partaking by Church members of the sacrament of Eucharist (Deneken 1988, p. 268). Indeed, Schillebeeckx calls to meditation on Christ's words during the Last Supper, depicting the phrase "for you", together with the submission to the Father's will and with Christ's own human will to serve the whole of humanity as the founding moment of human pro-existential life (Matthew 26:28,39): “The 'for you' (hyper formula), in the sense of Jesus's entire pro-existence, was the historical intention of his whole ministry and was substantiated by his very death" (Schillebeeckx [1987] 2004, p. 311). In this light, pro-existence is something to be achieved by somebody by simply taking Jesus's humanity as a model and orienting one's personal life towards the service of people, but always with the goal of honoring God, as Jesus did, in his founding pro-existential attitude of honoring the Father by serving humanity. Commenting on the same passages of the Scripture, Walter Kasper defines pro-existence as shared humanity, after the model of Jesus: "Human pro-existence (or shared humanity), but proceeding from God and to the honor of God: to that end Jesus was filled with God's Spirit and his very existence as a man was the work of God's Spirit" (Kasper [2007] 1976, p. 558).

Michel Deneken also sees in the Eucharistic theology of Karl Rahner and that of François Xavier Durrwell elements of Christological pro-existence. In Deneken's reading, Rahner's "anthropo-theology" of Christ's death as service to humanity represents a "key-moment" in "the understanding of Jesus" (un moment-clé de la compréhension de Jésus), since the moment of sacrifice is transformed in a moment of love for humanity (Deneken 1988, p. 274). In this point, Deneken shows the important place of theological reasoning on pro-existence in the framework of Christology, as it allows a renewal of theological reflection, a departure from old theological interpretations on Christ's service as sacrifice. Deneken acknowledges the twentieth-century Catholic departure from a sacrificial or legalistic interpretation of the phrase hyper, interpretations that had occurred due to a misleading exegetical reading of hyper as "in lieu of" (à la place de) instead of "for" (Deneken 1988, p. 270). In Deneken's view, the theology of the Eucharist facilitates "the shift from sacrificial to pro-existential" (le passage du sacrificiel au pro-existentiel) (Deneken 1988, p. 268).

According to Deneken, in the Eucharistic "gesture" (Deneken 1988, p. 267) during the Last Supper, Walter Kasper sees, as does Rahner, the moment of Christ's revealing as "the-man-for-the others" (l'homme-pour-les autres) (Deneken 1988, p. 271). When discussing the words "for us", "for the multitude", Kasper appreciates that the dimension of Jesus's service for the whole of humanity received a central place in the post-Paschal preaching of the Apostles (Deneken 1988, p. 271; Kasper 1980, p. 325), which explains their centrality in the sacrament of the Eucharist. In this spirit, Deneken concludes that the Last Supper of Jesus with the Apostles represents the essential place of pro-existence (la topique de la pro-existence) (Deneken 1988, p. 271). Arguing that, in his service, Jesus showed himself as "the brother" of all humans (Deneken 1988, p. 271; Kasper 1980, p. 325), Walter Kasper also argues for integrating the service for non-Christians and even the oppressors, the aspect so much emphasized by the first approach to pro-existence, into a Christian attitude of following the man Jesus's example: "Following Jesus meant following him in this service: If anyone would be first, he must be last of all and servant of all (Mark 9:35). Service, love which includes one's enemies, in short living for others, is the new way of living which Jesus inaugurated and made possible. A life like this involves being prepared for anything, leaving everything (Mark 10:28), even risking your life (Mark 8:34)" (Kasper [2007] 1976 , p. 377). This is similar to Schillebeeckx's approach to Jesus's examples in his humanity. The interpretations of both Kasper and Schillebeeckx leave the door open to interfaith dialogue, since the accent placed on following Jesus in his submission to God and service to people as a human does not necessarily imply faith in his divinity. 
If Kasper and Schillebeeckx widen the perspective of Jesus's example for each Christian, but also to all humans by virtue of their quality of "brothers" of Jesus in his humanity, Heinz Schürmann bases his reflection on Jesus's pro-existential service on the relationship of Jesus's submission to the Father's will, leading to a new anthropological dimension of pro-existence that follows the model of Christ's kenosis. First of all, Schürmann emphasizes that, when taking Jesus as an example, one should not forget that his attitude of service is an attitude of "submission" and "total self offering" to God, before being a gesture of accepting the sacrifice for all human beings (Deneken 1988, p. 272; Schürmann 1977, p. 166). The importance of Jesus's example lies in the fact of his human kenosis: if the kenosis in the incarnation of the Son is a widely discussed aspect in Christology, Schürmann initiated the reflection on a new type of kenosis, a "contemplative kenosis" (Deneken 1988, p. 277; Schürmann 1977, p. 181): in his pro-existential submission to Father's will and acceptance of the sacrifice for the whole of humanity, Jesus becomes "the man truly free, freed of his self", freed of the fears of his human self (Jésus est donc l'homme vraiment 'libre', libéré de lui-même) (Deneken 1988, p. 273; Schürmann 1977, p. 167). Following Jesus in this "contemplative kenosis", every Christian has to embrace the same pro-existential attitude of becoming free of his human self, free of everything that makes him fearful for his life, safety, or wellbeing.

This is indeed a bold understanding of Jesus's prayer to the Father (Matthew 26:39; Luke 22: 43-44; John 17:4), aligning the reflection with other theologians' embracing of the second approach to pro-existence, by reasserting Jesus's gift to God and humanity, during the founding moments of the sacrament of the Eucharist, at the center of every human search for service. Nonetheless, Schürmann's reflection also remains inclusive regarding the first approach to pro-existence, by the exhortation towards Christians to accept the "contemplative kenosis", which, during service to the non-Christian "brother", may sometimes require a self-inflicted deprivation of everything that makes a Christian life: a voluntary renouncement to the safe zone of one's own community while searching for the brother in need in the territories of different faiths, social systems, or political regimes. Furthermore, Schürmann talks about a process of "inculturation" of Christology according to different historical periods, as new ways of understanding Christ according to the ways in which the Scripture's message is understood in the midst of concrete historical situations (Deneken 1988, p. 276). Schürmann dedicates an entire article to this reflection on Jesus's pro-existence, an article published in the 1970s, but suggestively entitled as a question addressed to Christians everywhere: "Will the "pro-existent" Christ remain at the heart of tomorrow's faith?" (Schürmann 1977, pp. 145-87). By his call to total renouncement to our human fears, by which he may also understand giving up the fears of being deprived of the sacramental life of the Church, Schürmann's theology of pro-existence combines the two approaches of the reflection on pro-existence, making the first seem less radical, and the second become more dynamic.

Another perspective that seems to reconcile the two approaches comes from the Evangelistic theologian Walter Klaiber, who expands the Christological reflection of the words "for us" to Ecclesiological dimensions. Klaiber already sees, in the fact that the New Testament is composed of different writings addressed to specific needs of local communities, a post-Paschal application of Christ's Eucharistic words: "The New Testament is not a missionary writing [...]. It is a collection of writings for certain churches which cite this basic missional gospel in very different situations and utilize it for theological or teaching purposes. [...] Nonetheless a unity is recognizable. [...] The basis and power of this message lies in the certainty that 'God is for us', which is guaranteed by Jesus's message and his offering of life for us. The reality of God's pro-existence reaches human need in its entire complexity and breaks through the power of sin which draws its power from the isolation and the ego-centricity of humankind. The mission of the Church of Jesus Christ, whose witness, communion, and ministry is filled and formed by God's existence for us, is grounded in this" (Klaiber [2003] 1997, pp. 75-77). Klaiber's insistence on the application of Jesus Christ's attitude of "being for" God and people to the concrete situations of each community, brings his thought closer to the first approach in the theological reflection on pro-existence. The novelty of Klaiber's perspective lies in the fact that it alludes to the importance of recreating the unity of the Church from the bottom 
up, from the way diverse communities respond in the application of Jesus Christ's service to concrete local needs regarding the help due to the neighbor. Since the New Testament itself has emerged as a unified missionary and educational message in spite of its writings being dedicated to specific applications of Christ's message, there is no reason to suppose that a firmer institutional grounding in God's pro-existence at different levels like the ministry of the clergy, communion of the members, and the mission of being Christ's witnesses in a world ravaged by deep social unrest would not recreate the unity of the Church of Jesus Christ.

The continuity of the reflection on pro-existence in the twenty-first century can be seen in Pope Benedict XVI's use of the term "pro-existence" in his Jesus of Nazareth (Pope Benedict XVI 2011, pp. 134, 174); the ecological dimensions of pro-existence raised by the publication of the Evangelical theologian Udo Middleman in 1974 and the republication of the book in 2012 (Middelmann [1974] 2012); or the use of the term in feminist theology (Rösener 2002, p. 3). However, as my short presentation of the two approaches suggests, further work on pro-existence is needed in order to give more detailed answers to the challenge of integrating the service to "brothers" in concrete needs within the unity of Christ's body, the Church. The next section, dedicated to Dumitru Staniloae's Orthodox perspective on service and pro-existence, shows a series of aspects that resonate well with many elements of either of the two approaches emphasized in this section, and his further theological reflection on integrating the need for concrete service into the environment of a pro-existence sustained by the sacramental life of the Church.

\section{Dumitru Staniloae's Distinctive Orthodox Contribution to the Theological Reflection on Service and Pro-Existence}

"So it is not the Church we try to preserve now, but the Gospel" asserted Elisabeth Adler (Adler 1964, p. 13). Likewise, Sobrino's understanding of "partisan pro-existence" (Sobrino [1987] 2004, p. 34) suggested that the Church should more radically cultivate love to the one in special need than simply talking about God's love for all Christians or all humankind. The first approach can thus be interpreted as an attempt to apply to the concrete circumstances of life Christ's pro-existence as expressed in the parable of the Lost Sheep, where the good shepherd is ready to leave the ninety-nine sheep in order to rescue the one in danger (Matthew 18:12-14; Luke 15:3-7). The second approach in Catholic and Protestant theology, which faces the relativizing danger of a call to service aiming at transgressing religious boundaries, has generally maintained that fullness of service can only be experienced if Christians are nourished by Church's sacraments, especially by the founding words of the Eucharist as the full expression of Christ's self giving to God and absolute service to humans, and guided by the ministry of the clergy. At the same time, Heinz Schürmann's and Walter Klaiber's perspectives can be read as contributions in which elements of the first approach are considered essential to the life of Jesus Christ's Church, without necessarily having to assert a radical attitude of service. For instance, both theologians assert the need of the Church to regard the specific problems of a certain community or space in which a community lives as opportunities to inform and renew the Christian understanding of pro-existence, just as different historical periods have shaped new understandings of Christology, as part of a larger process of "inculturation".

In the manner of the second approach to pro-existence, the Romanian Orthodox theologian Dumitru Staniloae reflects on the possibilities of living service to the human brother as fully as possible, in relation to the beating heart that sets into motion the life of the Church: the Eucharist. Nevertheless, a closer look at both Staniloae's experience as a member of the Romanian Orthodox clergy under Communist persecution, and his theological understanding of service and pro-existence will show that, for him too, the concrete circumstances of life should play an essential role in situating oneself as a Christian within the Church, and situating the local Orthodox Church itself, led by a bishop, and all the Orthodox Churches, within the larger body of Christ. 


\subsection{Pro-Existing in Humbleness: The Oppressed, Their Need for Christ's Presence and the Response of the Incarcerated Orthodox Priests}

Fr. Dumitru Staniloae personally experienced the horrors of an oppressive system, his marginalization from the center of Romanian intellectual life having reached its peak in September 1958, when he was incarcerated due to his membership of Rugul Aprins (The Unburnt Bush). This cultural organization had organized small meetings in members' houses, and public conferences at the Antim monastery in Bucharest, having thus contributed to Romanian cultural life and to keeping alive the spirit of intellectual resistance to Soviet ideology (Botez 1992, p. 212). In an article published in 1990, Father Staniloae describes with modesty, in just a few words, some of the physical torments that he and his fellows endured during imprisonment, and gives the names of his cellmates who died in prison or shortly after being released. He also adds: "In prison, the Orthodox priests and monks did not just dwell, but taught people Akathist hymns and other prayers, written on pieces of soap with broken bars taken from cell doors; they gave lessons in the Christian catechism. In spite of all persecution and surveillance, the priests and monks continued practising their service, celebrating the Divine Liturgy, as well as baptisms, marriages and funerals. They continued preaching the word of God, and nobody ever heard any priest mentioning the tyrant in their sermon" [Author's transl.] (Staniloae 2003b, p. 284). Father Dumitru Staniloae shows the two attitudes shared by the incarcerated: first of all, the rituals of the Church helped them gain a sense of normalcy of life, a degree of inner freedom that no persecution could have taken away from them; secondly, while coming together in prayer, they never uttered words of contempt regarding their persecutors, suggested by the symbolic name "the tyrant". They simply followed Christ's example (Isaiah 53:7) that was included by the Christian Orthodox Tradition in the prayers of the Proskomedia, the ritual of the preparation of bread and wine for the Sacrament of the Eucharist. It is also striking that Orthodox priests and monks could have celebrated the Divine Liturgy and other Church sacraments and hierurgies without that which makes a Church visible in the eyes of a common Christian: without the building itself, without liturgical garments, without the bride and the groom being physically present in the same room, and even without bread or wine for the Eucharist. Fr. Staniloae does not give details on how all of this had been materially possible, since, according to his testimony, many of his fellow inmates died of starvation, a fact which would have practically made procuring bread very difficult, and practically impossible when it came to procuring wine for the Eucharist. He simply states that all these sacraments and hierurgies did actually take place, as a facet of the Church's service to the special need of Christ's brothers. Nonetheless, this did not weaken the Church in her visible presence, but rather intensified it, as the Church took the concrete situation in the prison as the starting point of her service, and continued her mission of bringing Christ at the table of the ones who needed his presence.

\subsection{Service as the "True" Dimension of the Church in the "New Social Era"}

In 1965, two years after his release, Father Staniloae was reinstated as a professor of theology in Bucharest, following a response by the regime who wished to generate a more positive impression among western intellectuals who were themselves demanding information on Staniloae's fate (Botez 1992, pp. 212-13). Already in 1963, the year of his release from prison, Dumitru Staniloae published in the Romanian Orthodox theological journal Glasul Bisericii (The Call of the Church) an article simply entitled "Servire și proexistență" (Service and Pro-existence), mentioning that he took the term pro-existence from the proceedings of the Christian Peace Conference (Staniloae 1963, p. 1019). Staniloae's contribution to the reflection on pro-existence that generated the two approaches mentioned in the first section of this article places in balance both the need for Christians to take as a point of departure the concrete situations of certain persons or communities in order to find the best answer to their needs, and the Church's vocation of offering the plenitude of her gifts to those animated by faith in Christ's pro-existence.

Given the fact that the concrete circumstances may inform the pro-existential attitude of Christians towards concrete service to people in need for specific solutions, in his 1963 article Staniloae chooses 
to talk first about service, by pointing to the fact that Catholic and Protestant Churches have a long and uncontested experience in serving, not only individuals, but especially communities. In the opening of his 1963 article, Staniloae quotes from the Japanese Protestant theologian Masao Takenaka's intervention during the World Council of Churches's third General Assembly of New Delhi (1961), emphasizing that, although the "dimension of service" remains the essential feature of Christ's Church, it is the concrete "new", "communitarian structure" of the international context that has "helped" the Church "rediscover" new ways of accomplishing her call (Staniloae 1963, p. 1019). Staniloae goes as far as asserting that this "new" dimension emphasized by Takenaka actually represents the Church's "true" dimension (Staniloae 1963, p. 1020), an attitude that might seem compatible with the aspect of "inculturation" in Christology discussed in Schürmann's case, this time also extended to Ecclesiology.

Staniloae advances further towards a peculiar argument of "inculturation" regarding Ecclesiological renewal given the opportunity of the reevaluation, within each local Church, of the role of service that is becoming more and more necessary under the pressure of international instability. The growing necessity of serving not only individuals, but also entire communities, has led to the emergence of international organizations dedicated to service. According to Staniloae, right from the first meeting of the Second Vatican Council, the Catholic Church has reacted to this situation by the official "renouncement" of any "tendency of domination" in the Church, a measure accompanied by the more practical rule for the clergy to divest themselves of the "royal garment" and instead to don the "coat of humility". Moreover, "a special merit for the emphasis placed nowadays on Christian 'service' within the Ecumenical Movement belongs to Protestant theology". Staniloae believes that the "salutary rediscovery" of service in the Protestant theology has come as a "special joy" for the Church, since this rediscovery "represented a return from the individualism of the original protestant doctrine, which had dissolved the community" [Author's transl.] (Staniloae 1963, p. 1021).

\subsection{The Necessity of a Renewed Sense of Service in the Orthodox Church: From Humbleness in the Face of Oppressive Political Authority, to Humbleness Regarding the Authority of the Clergy}

By contrast, service in the Orthodox Church "has always been practised as something self-evident". However, this also explains the insufficiency of the Orthodox theological reflection on the dimensions of service in "the new social era": "What is needed today from the Orthodox Church as well is both the necessary theological clarification of the notion of service, and its increased application in an Orthodox spirit" [Author's transl.] (Staniloae 1963, p. 1021). In other words, given the new special circumstances of the "new social era", both Catholic and Protestant Churches have come closer to the Orthodox understanding of service, although paradoxically, the Orthodox Church does not respond adequately to this phenomenon, but rather follows the old trends of those western Churches. An "inculturation" process in Ecclesiology as a new understanding of Church unity based on Christ's "act of boundless service" is not only desirable, but necessary, not only because the Orthodox Church is not sensitive enough, or does not organize herself well enough to respond more urgently to situations requiring concrete help, but also because, throughout her history, the Orthodox Church has not been able to fully observe the complexity of Christ's example, in spite of her openness to doing so: "The Orthodox Church preserved, as much as circumstances allowed, a part of the spirit of community of early Christianity" [Author's transl.] (Staniloae 1963, p. 1021).

The striking assertion that the Orthodox Church has only preserved a "part" of Christ's example of service should not be understood as a radical call, similar to the first approach to service and pro-existence emphasized above, but rather as a call to humbleness: the Orthodox Church has always been under the negative pressure of the "structure and mentality of an individualistic society", which she always chose to counter by humbleness. "Humbleness, united with the feeling of fraternity and equality, preached and applied throughout her area of jurisdiction, had bridled the tendency towards arrogance" [Author's transl.] (Staniloae 1963, p. 1021). This a humble way of suggesting that, at the time of the article, the Orthodox Church was, as in the past, under the pressure of a certain "structure and mentality" that was promising "equality" and "fraternity" without liberty. Thus, the 
Church's mission had always consisted in the work of proposing humbleness as a substitute for liberty, humbleness as internal liberty paired with Christ's attitude of readiness to suffer without retaliation, as prophesied: "He was oppressed, and he was afflicted, yet he opened not his mouth" (Isaiah 53:7). At the same time, this carries the risk of an incorrect understanding of humbleness by the clergy themselves, who, in their great eagerness to escape being supervised by a superimposed earthly authority and their great confidence that some truths are "self-evident" in the teaching of the Church, would rather renounce any further enquiry and try to look for discourses complacent with the ideological trends of the time. The humbleness of the Orthodox way is thus not the one that transforms the clergy into a quiet instrument of a political regime that, in spite of its official endorsing of equality and fraternity, leads in practice to a more acute individualism. Admitting that the hierarchy of the Orthodox Church made mistakes every time the clergy tried to borrow attitudes preached by the political power in the name of equality and fraternity, would be an important step towards embracing a kind of humbleness that would reorient the Orthodox Church towards the true meaning of Christ's teaching and example.

There are three challenges ahead for the Orthodox clergy, Staniloae believes. The first is the harmonious joining of both service to God, which he renders by the Greek term leitourgia, which in Romanian has been translated by the term "slujire", and service to people, represented by the term diakonia, in Romanian being called "servire", although in practice the first term, "slujire" is wide enough to express both meanings in Romanian, service to God (worship) by service to people: "It is fair to admit that the Church has been preoccupied in the past rather with the service to God in the strict sense of the word, that is with the "divine service" (sfintele slujbe). Still, the refreshing of the Christian life from the spring of the New Testament should help us avoid dissociating "service-worship" (slujirea) to God from "service" (servirea) to people. Only in the "service" (servirea) to people is the "service-worship" (slujirea) to God fully accomplished" [Author's transl.] (Staniloae 1963, p. 1025).

The second challenge, even for the common priest, will be to find adequate ways of serving "beyond the divine service and the preaching of the word", especially because even small communities may be affected by problems which the priest "will not define himself" to his community, but will be "imposed to him by the specific needs of the people among whom he lives, believers or non-believers" [Author's transl.] (Staniloae 1963, pp. 1025-26). This is a special reminder for the Church hierarchy not to fall into ideological rigidity, or mislead the members of the Church by defining in an erroneous way the specific need for service of a certain person or number of persons as a potential threat for the integrity of faith of the community as a whole, even when the persons in need are not believers.

\subsection{The Necessity of a Unified and Coherent Effort of the Orthodox Churches in the Context of Global Challenges}

The third challenge for the Orthodox Church hierarchy is to find ways to allow local Churches to come together and produce a coherent message that would be translated into a visible unified effort comparable to the effort of other Churches and non-Christian institutions dedicated to the service of specific human problems: "When emphasizing the requirement of service that is to be expected from the Church as a whole, as distinguished from the personal service of each Christian, we need to take into consideration the fact of the existence of iniquities or threats of a more general order, which cannot be overcome simply by individual actions, but which require the common action of all peoples and institutions. It is the case with the contemporary world's threat of an atomic war. Tackling this threat requires the firm action of the humanity as a whole and necessitates at the same time the service of the Church, or to put it more clearly, the service of the Churches as integers (întreguri) in each part. There are also other problems, which inflict suffering to peoples and large numbers of human beings, and preclude the development of humanity: racial persecutions, cultural backwardness, extreme poverty and sickness of a large segment of population from different parts of our planet" [Author's transl.] (Staniloae 1963, p. 1026). Catholic and Protestant Churches have proven their ability to respond to the new problems of the humanity as a whole by coming closer to the spirit of 
the Orthodox understanding of service, whereas the Orthodox Churches have major difficulties in finding ways to organize themselves around the principle according to which each local Church is the whole Church manifested according to the particular political, social, or cultural settings. The solution envisaged by Staniloae is only suggested in the article dedicated to service and pro-existence, and is developed subsequently.

In the 1963 article, Staniloae believes that one reason for this insufficiency in bringing about a unified decision and action comes from the import of the distinction between Militant and Triumphant Church in the Orthodox ecclesiology, a separation abandoned by the Catholic Church at the Second Vatican Council. This distinction is damaging for the Orthodox Church in the sense that her clergy embrace either a political messianic mission, against the existing structures, or simply slip into collaboration with the political power, since at first sight, the ideology of equality and fraternity seems compatible with the mission of the Church, praising both social stability and the establishment of a social order capable of offering a certain degree of safety from the external potential threats. The second attitude, nourished by concrete social and political situations, leads local Churches to reach an "individualistic" mentality, with the consequence of arrogating for themselves in practice, although not theologically, the authority of the whole Church: "It is not for nothing that Dionysius the Areopagite assimilates the role of the three hierarchical ranks of the Church (deacons, priests, bishops) with that of the angels, something that the Book of Revelation had done with the rank of bishop (in Chapters 2 and 3), because angels themselves are servants. The 'fight' of the Christian or the Church can only be understood as service" [Author's transl.] (Staniloae 1963, p. 1026).

In another article, published in 1977, Staniloae went on to propose a theological term intended to clarify the ways in which each local Church may present herself as a representative of the Church as a whole. This term is "sinodicity" (sinodicitate), which he first describes as similar to the term "sobornicity" (sobornicitate) (Staniloae 1977, p. 611). In the field of Ecumenical studies, Dumitru Staniloae is known for having proposed the term "Open Sobornicity" to express the inclusive attitude of the Orthodox Church towards the doctrinal and spiritual advancement of the Catholic and Protestant Churches towards an Orthodox perspective (Turcescu 2002). This time, he intends the term "sinodicity" to mean not interconfessional dialogue, but the dialogue between the Orthodox Churches in their goal of regenerating the understanding of sobornicity and coming together in one coherent body. Describing the function of the bishop leading the local Church, Staniloae asserts that the bishop helps manifest the whole presence of the Church in the local part led by him, in a similar way to Christ's presence in the Eucharist: "The transformation of the gifts into the Lord's body and blood is accomplished by the priest with the invocation of the Holy Spirit, although not in isolation from the atmosphere of prayer of the community; similarly, the ordination of the bishop is accomplished by the invocation of the Holy Spirit by the ordaining hierarchs, although within the atmosphere of a liturgical community [...]. That is why, right from the initial moment of his quality and service, the bishop is 'pars in toto', not 'pars pro toto'“'[Author's transl.] (Staniloae 1977, p. 613).

Thus, the bishop cannot simply substitute, in an individualistic way, the wholeness of the Church for the wholeness or the "integer" of his community. Moreover, Staniloae argues that, by virtue of this ordination accomplished by several bishops as a visible sign of the "liturgical community" across the Orthodox Churches, the bishop has the prerogative of participating in a general council "without having to receive a special empowerment from the members of the Church, although he represents the pleroma of his Church during the council and at all times." Staniloae is aware that the preparation for a "synod" of the Churches requires a considerable amount of time and work spent in creating an agreement and unity of perspective not only between the participating groups of clergy, but also an internal coherence of each local Church before the departure of the clergy to take part in the synod: "In other words, the Church prepares the statements, and is preparing herself for the resolutions to be taken by the synod, and within this framework the bishops are preparing themselves as well; and it is still up to the Church to establish later if the formula agreed upon [during the Council] corresponds to 
the essence of the preliminary conclusion that had emerged from her experience and reflection as it was reasoned prior to the Council" [Author's transl.] (Staniloae 1977, pp. 613-14).

This extended argument shows Dumitru Staniloae's view that a more decisive response of the Orthodox Church as a whole regarding global challenges is possible, provided that the local Churches renounce their individualistic inclinations that have affected the functioning of sobornicity, and embrace the humility of acknowledging that the ambition of a local Church to talk "pro toto", for the entire body of the Church, should be countered with the attitude of following the example of Christ who "washed the feet of his disciples and gave the parable of the Samaritan who washed the wounds of the one who fell among robbers" [Author's transl.] (Staniloae 1963, p. 1026). In the framework of Staniloae's argument, the figure of the Samaritan may account for the Catholic and Protestant Churches, since he chose to open the article dedicated to service and pro-existence with examples of their advancements in following the biblical service. The actions of the Catholic and Protestant Churches should not be overlooked by the Orthodox Church, and neither should the Orthodox Church overlook the actions of other international organizations. Given the situation created by the new international context—a situation dominated by urgent problems like nuclear threats, racial discrimination, cultural backwardness, extreme poverty, sickness, and the like-service becomes not only a desideratum, but a necessary activity of the secular international world, so that "no human being and no human organization can elude this general trend, far less the Church, as she has at her very foundation an act of boundless service" [Author's transl.] (Staniloae 1963, p. 1020). This perspective places Staniloae in a position which is incompatible to that of Aidan Nichols, who had disapproved of the idea of compatibility between the Church and other human "aggregates", with which, in Nichols's view, the Church can only have a relation of "co-existence", in spite of their philanthropic activities. As we will see further, the reason for the peculiar position of Fr. Dumitru Staniloae comes from his theological understanding of the attitude of pro-existence.

\subsection{Staniloae's Specific Understanding of "Pro-Existence" and Its Implications for the Orthodox Church's Attitude to Service}

If the Catholic and Protestant theologians emphasize Christ's self-sacrifice as the initiator of human pro-existence, in Staniloae's thought, the perspective is much wider: pro-existence is seen as an "ontological fact" (Staniloae 1963, p. 1027), being given by God to Adam and Eve from their creation, and it is not lost with the fall, because it has always been, in human history, closely connected to co-existence: "The term 'pro-existence' means the existence for the other. It emphasizes a certain aspect of the term 'co-existence'. 'Co-existence' means the together existence of many. But it does not express only an appended existence, but rather a certain community of existence [...]. In a way, the ones that co-exist reciprocally help each-other to exist. This community of existence is stated more clearly from a certain perspective by the term 'pro-existence'. For each of those that co-exist, to exist together with the other means also, among other meanings, to exist for the other. It is obvious that, in this way, pro-existence expresses a deeper, more fundamental engagement of each human being towards others than service, but also the want that each one has for the existence of the other. [...] 'It is not good for the man to be alone' says already the first page of the Holy Book of the Christian Revelation. 'I will make a helper suitable for him'; this is the role of a human being side by side with another human being: to be 'a helper suitable for him' (Genesis 2:18)" [Author's transl.] (Staniloae 1963, p. 1027). First of all, pro-existence is identified by Staniloae even in the attitude of co-existence, since existence for each other is unavoidable, as this is a condition of society. The dimension of pro-existence thus only serves to emphasize the existing aspect of reciprocal existence implied in co-existence. However, this doesn't mean that the minimal pro-existence included in the reciprocal help manifested with co-existence fully accounts for all the generous acts manifested in the world since the beginning of human existence. The minimal level of pro-existence included in co-existence would not explain the philanthropic acts that are carried out in the complete absence of any self-interest. Staniloae's argument for this second, autonomous level of natural pro-existence is "the want that each one has for the existence of the other". 
In other words, one can feel the need to be in the presence of the others in a more practical way, the division of labor being among the aspects that would correspond to a level of "being for" included in co-existence, but it would be hard to explain by this aspect of co-existence the need to love and be loved, or the need to help and be helped in a non-selfish way, as these needs are given by God to Adam and Eve, and manifested by all human beings before Christianity. Pro-existence is an "ontological fact", asserts Dumitru Staniloae. Indeed, Staniloae admits, the ontological restoration accomplished by Christ in his pro-existent attitude enlarges the horizons of pro-existence: "The ultimate cause and finality for Christians is God" (Staniloae 1963, p. 1027).

This perspective explains Staniloae's claim that Christians should serve not only believers, but unbelievers as well, and that the service to God or worship (leitourgia) should not exclude service to people (diakonia). In another article focusing on the topic of service and published in the "Pastoral Guidance" section of the journal "Romanian Orthodox Church", being thus intended as a theological resource for priests, Fr. Staniloae argues: "By Serving people we do not give the tithe of our service to God, we do not steal from the time and full attention owed to the service of God, but actually we serve God by accomplishing His commandment" [Author's transl.] (Staniloae 1970, pp. 409-10). If the project of the Catholic theologians was to go beyond a sacrificial and legalistic understanding of Christ's pro-existential gesture of suffering death for all humankind (Deneken 1988, p. 270), Dumitru Staniloae's project was to go beyond a ritualistic understanding of worship in the Orthodox Church, which was, in his view, linked to a kind of sacrificial understanding of the service to people. If co-existence means occasionally existing for others, with the feeling of sacrificing one's own time and energy, this might appear acceptable for an Orthodox Christian, since this would involve giving the tithe of our own profit for the glory of God, but having to give the tithe of our own worship, this would seem unacceptable, first, because even if Christians prayed day and night, they would still not bring enough service to God by worship, and second, because this may engender a bad habit of choosing to sacrifice time for prayer when trying to help the other, rather than sacrificing from our private time and, thus ultimately endangering our own hope for salvation. As we have seen, Staniloae does not agree with this kind of attitude, first of all because a natural pro-existence inclines even non-Christians to carry out unselfish acts, even if they do sacrifice a large part of their own time and profit, and also because if the Christian embraces a renewed pro-existence in Christ, $\mathrm{s} /$ he will choose in a non-selfish way to serve God by serving the neighbor.

Furthermore, it can be argued that there is an undeniable degree of compatibility between the natural pro-existence and the Christian pro-existence, by taking into account Fr. Dumitru Staniloae's view on the place of the world as a space of communion between people and of people with God. Fr. Marc-Antoine Costa de Beauregard, who spent the summer of 1981 at the Monastery Cernica interviewing the Romanian theologian, writes that, in Staniloae's thought, the world itself becomes "a space of communion and a space of liberty", and that it is in this space that God showed that his creation is for the human being, as all the animals are brought to him as God's gift, "revealing thus the trinitarian, that is, relational form of the created space" [Author's transl.] (De Beauregard 2002, p. 149; De Beauregard 1983, pp. 169-79). Indeed, Staniloae's vision on the vocation of Christian pro-existence to embrace all natural pro-existence and co-existence with human beings, animals, and the entire material universe as a space of love can be observed from an article published in 1972: "When we share in the material goods of the universe we must be conscious that we are moving in the sphere of Christ, and that it is by making use of these material things as gifts for the benefit of one another that we progress in our union with Christ and with our neighbor. [...] Thus the universe is called to become the eschatological paradise through the agency of fraternal love. It is our duty to free the universe from the vanity of the blind and selfish use we make of it as sinners, and to see that it shares in the glory of the sons of God (Rom. 8:21), the glory which is an inseparable part of our union as brothers" (Staniloae 1980, p. 212).

It remains to be clarified why Fr. Dumitru Staniloae sees pro-existence as a deeper engagement than service. Staniloae's explanation resides in the way he defines pro-existence as compared to service: 
“The term 'service' expresses a voluntary engagement. It expresses the idea that, once I exist, I can and I am obliged to work towards others. Service is added to my existence; and through service I add something to others' existence. The term 'pro-existence' expresses the fact that in my very existence is imprinted the dynamic reference towards the other, as a primary finality in this world, and that [this imprinted reference] is given and is being fulfilled through the reference of other existences towards myself. Service is nothing but the moral consequence of the ontological fact of pro-existence. If serving means working for the other, pro-existing means more: to exist for others. Pro-existence ontologically excludes egoism. Egoism is a perversion, an 'alienation' of human nature" [Author's transl.] (Staniloae 1963, p. 1027). If human beings can be forced to serve, they cannot be forced to pro-exist, since pro-existence is an ontological feature of humanity given from Creation. Moreover, we can learn how to serve, but pro-existence is fundamental to human nature. By their egoism, human beings merely deter pro-existence from manifesting itself in their hearts: "When we impeach the pro-existential impetus coming from our inner selves, we impeach the manifestation of other people's pro-existence towards us" [Author's transl.] (Staniloae 1963, p. 1029).

This assertion is essential in the context of Staniloae's advice to priests not to define the concrete problems themselves, but to wait for the persons affected by those particular problems to define them. The danger that the priest may generate is to spread fear or "individualistic" mentality among the members of the community, which would effectively deter the "pro-existential impetus" to be manifested towards those that the members of the community perceive as potential enemies. Staniloae is thus aware that an ideological reading of the neighbors' problems may reorient towards a more limited or safer manifestation of love, limited only to those we completely know and trust. However, this means advancing towards a biased understanding of the Christian imperative of love for the enemy.

There is, indeed, an important risk associated with pro-existing towards, or communing with, the enemy. Staniloae gives a series of Scriptural arguments to show that Christians should embrace this calling and face the danger, even when this means being sacrificed (John 5; 7:19; 10:10; I John 3: 14-16) (Staniloae 1963, p. 1029). Nonetheless, Christians should not be afraid of this extreme situation, because the extreme cases can be avoided by using the most characteristic medium of communication of human beings, the word: "The pro-existential character of the human person is probably nowhere manifested to such a high extent than in the word which constitutes the person's most defining and comprehensive spiritual attribute, according to the Holy Fathers' definition: the human being is an animal endowed with speech. [...] Through the word, human beings become attached to each other, they support each other, they weave connections and make communal advancements. Within the word, human beings themselves join each other, ceasing to be distant from each other. [...] This is adequately suggested by the Romanian term 'cuvânt', which comes from the Latin 'conventus', encounter, fusion, coming to the same place. [...] The word-command, when it is not covered by the authority of the whole community [...], represents an 'alienation' of the role of the word, an 'alienation' of nature from its thirst for communion and a deprivation of the chance to advancement in communion and meaning. [...] The human being has the power of refusing to serve and the capacity to use the word towards discord and disunion, and this tends to the weakening of the humanity" [Author's transl.] (Staniloae 1963, pp. 1027-28). The individualistic word does not reflect the communal liturgical experience and reasoning of the ways in which the pro-existential impetus should be expressed in actual service. Even if endowed with a special status and ministry, the members of the hierarchy cannot use the word towards strengthening their authority, and should not use their influence to predefine the problems to be tackled by the community. The concrete problems will be acknowledged directly from those who suffer and, according to the principle of sinodicity, the whole Church will become active in each particular local community thanks to an active consultation and reasoning among her members and a fraternal debate between the clerics of different localities, thus opening up the possibility of reaching a decision that would reflect the service involving all the love the community can give.

Serving Christ's brothers in need, not necessarily through a preferential treatment of some of them, but rather by using the exchanged word in order to reach to the understanding of the concrete 
circumstances affecting their lives, may be a good opportunity to coagulate the Church as one body, able to follow the love commandment transmitted by Christ, her head. If Staniloae encourages the members of the Church towards an attitude manifesting itself through the word as a question awaiting an answer, one may ask if by this question and answer Staniloae means the predication of word to nonbelievers while serving them. To answer this challenging question, Staniloae responds that, besides the specific mission of preaching "the word of salvation", there is "the other mission, carrying a larger significance, which has the role of the word spoken from the roofs, endowed with universal reach, a mission of service towards helping the entire world come closer to the Kingdom of heaven, the Kingdom of love" [Author's transl.] (Staniloae 1970, p. 415). Only after this is accomplished can Christians move on to the more specific mission of baptizing those who discover in their hearts a faith in Christ.

\section{Conclusions}

Although Dumitru Staniloae's arguments on service and pro-existence may seem like a radical affirmation of an attitude that would weaken Christians' attachment to the institutional and sacramental life of the Church, the elements presented here have emphasized that the Romanian theologian placed these arguments into a specific Orthodox framework of understanding that precludes any radical reading. However, Staniloae's view cannot be completely assimilated to the second approach to service and pro-existence, emphasized in the first section of this article, since this second approach tends to represent pro-existence as an exclusively Christian attitude; it sees pro-existence to be founded by Christ's self-giving for humanity's restoration. There are, indeed, elements that would bring Staniloae's theological understanding closer to the second, non-radical approach, which integrates service and pro-existence in the sacramental and institutional life of the Church. However, Staniloae identifies pro-existence within a wider theological framework, which opens up the way of a broader understanding of the human effort towards serving the brother in need. Both Schürmann and Durrwell have conceived pro-existence as an important ingredient of the dynamic aspect of God's creation, suggesting the possibility of a cosmic evolution towards God's understanding. What is strikingly original in Staniloae's Orthodox understanding is his insistence on seeing pro-existence as an ontological "fact", and on a deeper level than service. This vision opens up numerous possibilities of conceiving not only Christians' path towards God, but the vocation of the whole of humanity and the entire Creation to advance in the communion with God, although this calling has been materialized many times in ways totally opposed to the "ontological fact" of "being for" other, given the human attraction for a rather egoistic satisfaction of the primordial thirst for communion.

Although at first sight Staniloae's thought tends to infuse relativism into the importance of the Church's life and, ultimately, the importance of being a Christian, Staniloae's aim is to explore the mysterious level of the human being's heart where faith appears in a way known and inspired only by God. Acknowledging a pro-existential "impetus" in each human heart, Staniloae does not advance, as in western theology, towards an "understanding of Christ", or towards an understanding of Christ's humanity in the pro-existential gesture, but rather he talks of a knowledge of God in the concrete circumstances of life. This kind of knowledge of God is the key towards both the renewal of the Christian's faith as part of a process of rediscovering Christ's brothers in need, and the advancement on the path towards the discovery of faith by somebody who is not a believer. This is intended to avoid the misconception that a Christian would be entitled to preach his faith to the one he is serving. Staniloae suggests that this equates closely to manipulation.

While in his particular approach to pro-existence he deepens the western theological reflection, his major aim is not to enter into theological dialogue with the western perspective, but to reinvigorate both the theological reflection and the moral practice of service in the Orthodox Church, by raising attention to both aspects, internal and external, of the Church's service. Regarding the internal aspect of service, Staniloae wants to encourage the Orthodox clergy to renounce the temptation of domination, a temptation which he sees as emerging as a consequence of the social mentalities of the day. Being 
immersed in a concrete socio-political setting, Staniloae observed that, in spite of an ideological discourse where fraternity and equality were praised, the reality concretely showed an ever-restrained liberty and a lapse towards sheer individualism. His encouragement towards the Orthodox clergy to move away from the ambition of domination comes also with the argument that both the Catholic and Protestant Churches, although troubled by a history of individualistic applications of service, have undeniably advanced towards an attitude compatible with that traditionally observed by the Orthodox Church. At the time he was writing the article, Staniloae meant to use the argument of the "coat of humility" taken by the Catholic clergy as an encouragement addressed to Orthodox priests that the Catholic Church, by rediscovering the poverty of the clergy, has made an important advancement in the understanding of service, and that, in spite of many material difficulties, service is effectively possible for the Orthodox clergy as well. Fr. Staniloae writes these lines having in his heart the ancestral image of the Romanian villages with their old churches built out of clay, but kept clean and attractive in their simplicity by the members of the community, and by the priest who preached the word of God and celebrated the Divine Liturgy and the other hierurgies rather using only one pair of garments and only one set of sacramental tools for decades. For example, in an article written in 1941, he asserts that the "life of the village" appeared, in its simplicity, so closely connected with the simplicity of the sacramental life, that it had been depicted by Staniloae as "a sacrament, a mystery, as vast in his visible aspect as the entire space inhabited by Romanians" [Author's transl.] (Staniloae 2003a, p. 129). Nevertheless, when writing the 1963 article, Staniloae also thinks of a world divided by the walls of national sovereignty and the spheres of dominance of world powers.

Many things have changed since then, both in what concerns the national status of the Orthodox Churches in the Eastern Europe, and the international landscape. However, now as then, the Orthodox Church faces both external challenges, that come from the rapid developments of the globalized world, and also internal difficulties in coming together with a unified voice for tackling the issue of serving the members of the Church, the members of non-Orthodox Churches, and the members of humanity who are nevertheless Christ's brothers. His theological perspective on "sinodicity" invites to a more transparent process of communication within and between the local Churches. The risk identified by Staniloae lies in the fact that the inner attachment of some members to one local Church might be deeply harmed by the decision of another local Church to dispute the adoption of a decision or document with potential normative applicability for the whole Church. That is why he insists that no local hierarchy has the authority to engender disorientation in the hearts of the members of other local Churches, and that no local group of people has the authority to generate factions within the local Church by following the decisions of other local Churches. In order to prevent such a phenomenon, Staniloae insists upon the need for communication between the hierarchy and the members of each particular Church, both prior to, and after signing such a document.

The nature and role of "sinodicity" remains one of the burning issues of the Orthodox Church as she faces the challenges of the contemporary world. More debate is needed, not only between theologians or members of the clergy, but rather as a wider process of the Orthodox Churches coming together and working together in the eyes and hearts of their members. This would have the undeniable effect of bringing the clergy closer to the actual issues of the contemporary world, and departing from attitudes of identifying their increasing loss of authority with the external dangers (the so-called invasions of sects, secularism, migrants, enemies of faith, new world order, and the like). These pre-defined issues mechanically repeated in sermons only do great disservice to the life of the communities, making future Orthodox Christians incapable of harmoniously integrating disinterested service to people within their faithfulness to the Orthodox Tradition.

Fr. Dumitru Staniloae believes that, by making more visible the "pleroma" of the Church as a web of harmonious relations between the clergies of different local Churches, and by bringing the pro-existential human impetus to its application in missions of service dedicated to concrete problems troubling diverse communities, not only will the Orthodox Churches contribute to the reinvigorated understanding of membership of individual Orthodox Christians to their Tradition, but the local 
Churches will also discover new capabilities in bringing back the lost sheep, and make way for God's work of faith in the hearts of all humanity.

Conflicts of Interest: The author declares no conflict of interest.

\section{References and Notes}

Adler, Elisabeth, ed. 1964. Pro-existence: Christian Voices in East Germany. London: SCM Press LTD.

Allen, John L., Jr. 2007. CELAM update: The Lasting Legacy of Liberation Theology. National Catholic Reporter, May 24. Available online: https://www.ncronline.org/news/celam-update-lasting-legacy-liberationtheology (accessed on 14 March 2017).

Pope Benedict XVI (Joseph Ratzinger). 2011. Jesus of Nazareth. Part Two: Holy Week, From the Entrance into Jerusalem to the Resurrection. San Francisco: Ignatius Press.

Bock, Paul. 1992. Protestantism in Czehoslovakia and Poland. In Protestantism and Politics in Eastern Europe and Russia: The Communist and Post-Communist Eras. Edited by Sabrina Petra Ramet. Durham and London: Duke University Press, pp. 73-106.

Bonhoeffer, Dietrich. 1959. Prisoner for God; Letters and Papers from Prison. Edited by Eberhard Bethge. Translated by Reginald H. Fuller. New York: The Macmillan Company.

Botez, Victor. 1992. Missionaire du sacré: Une interview du Père Dumitru Staniloae. In Philosophes Roumains; Repères Universels. Edited by Victor Botez, Valentin F. Mihaescu and Nicolae Sarambei. Bucharest: Rédaction des Publications Pour L'étranger, pp. 200-19.

De Beauregard, Marc Antoine Costa. 1983. Dumitru Staniloae: Ose Comprendre Que je T'aime. Paris: Cerf.

De Beauregard, Marc-Antoine Costa. 2002. Le cosmos et la croix. In Dumitru Staniloae: Tradition and Modernity in Theology. Edited by Lucian Turcescu. Iasi and Oxford: The Center for Romanian Studies, pp. 147-65.

Deneken, Michel. 1988. Pour une christologie de la proexistence. Revue des Sciences Religieuses 62: 265-90. [CrossRef]

Gibson, David. 2015. Liberation Theology's Founder Basks in a Belated Rehabilitation under Pope Francis. National Catholic Reporter, May 7. Available online: https:/ /www.ncronline.org/news/people/liberationtheologys-founder-basks-belated-rehabilitation-under-pope-francis (accessed on 14 March 2017).

Klaiber, Walter. 1997. Call and Response: Biblical Foundations of a Theology of Evangelism. Nashville: Abingdon, pp. 75-77. Quoted in Scott J. Jones. 2003. The Evangelistic Love of God and Neighbor: A Theology of Witness and Discipleship. Nashville: Abingdon Press.

Kasper, Walter. 1976. Jesus the Christ. Wellwood: Burns and Oates, p. 120. Quoted in Eamonn Mulcahy. The Cause of Our Salvation: Soteriological Causality according to Some Modern British Theologians 1988-1998. Rome: Editrice Pontificia Univesità Gregoriana, 2007.

Kasper, Walter. 1980. Jésus, le Christ. Paris: Cerf.

Middelmann, Udo. [1974] 2012. Pro Existence: The Place of Man in the Circle of Reality. Eugene: Wipf \& Stock.

Nichols, Aidan. 1992. 'Non tali auxilio': John Milbank's Suation to Orthodoxy. New Blackfriars 73: 326-32. Quoted in Alan Thomson. 2014. Culture in a Post-Secular Context: Theological Possibilities in Milbank, Barth and Bediako. Cambridge: James Clarke \& Co., p. 138.

Rösener, Christiane. 2002. 'Your People Shall Be My People, and Your God My God.' The Shared Life of Ruth and Naomi as a Model for Women Transgressing Intercultural Boundaries. In Transgressors: Toward a Feminist Biblical Theology. Edited by Claudia Janssen, Ute Ochtendung and Beate Wehn. Collegeville: The Liturgical Press, pp. 1-8.

Schillebeeckx, Edward. 2014. Collected Works, Vol. VI: Jesus: An Experiment in Christology. London and New York: Bloomsbury T \& T Clark.

Schürmann, Heinz. 1977. Comment Jésus A-T-Il Vécu sa Mort. Paris: Cerf.

Sobrino, Jon. [1987] 2004. Jesus in Latin America. Eugene: Wipf \& Stock, 2004.

Staniloae, Dumitru. 1963. Servire si Proexistenta (Service and Pro-existence). Glasul Bisericii (The Voice of the Church) 11-12: 1019-30.

Staniloae, Dumitru. 1970. Slujitori ai lui Dumnezeu, slujitori ai oamenilor (Servants of God, Servants of People). Biserica Ortodoxa Romana 3-4: 408-16.

Staniloae, Dumitru. 1977. Natura Sinodicitatii (The Nature of Sinodicity). Studii Teologice 9-10: 605-14. 
Staniloae, Dumitru. 1980. The Orthodox Doctrine of Salvation and Its Implications for Christian Diakonia in the World. In Theology and the Church. Written by Dumitru Staniloae. Translated by Robert Barringer. Foreword by John Meyendorff. Crestwood: St. Vladimir's Seminary Press, pp. 181-12. Originally published in Romanian, in Ortodoxia 24 (1972): 195-212.

Staniloae, Dumitru. 2003a. Crestinism si traditie in viata nationala (Christianity and Tradition in the Life of the Nation). In Dumitru Staniloae: Natiune si Crestinism. Edited by Constantin Schifirnet. Bucharest: Clion, pp. 123-33. Originally published in Luceafărul, I, nr. 2,1941: 42-48.

Staniloae, Dumitru. 2003b. Prigonirea Bisericii Ortodoxe stramosesti sub comunism (The Persecution of the Orthodox Church of Our Ancestors). In Dumitru Staniloae: Natiune si Crestinism. Edited by Constantin Schifirnet. Bucharest: Clion, pp. 283-85. Originally published in Ortodoxia XLII 1 (1990): 197-200.

Turcescu, Lucian. 2002. Eucharistic Ecclesiology or Open Sobornicity? In Dumitru Staniloae: Tradition and Modernity in Theology. Edited by Lucian Turcescu. Iasi and Oxford: The Center for Romanian Studies, pp. 83-103.

(C) 2017 by the author. Licensee MDPI, Basel, Switzerland. This article is an open access article distributed under the terms and conditions of the Creative Commons Attribution (CC BY) license (http:/ / creativecommons.org/licenses/by/4.0/). 